\title{
Reactivity thresholds in children allergic to cow's milk and egg, but tolerant of baked milk and baked egg.
}

\author{
Alessandro Fiocchi ${ }^{1}$, Rocco Valluzzi ${ }^{1}$, Carla Riccardi ${ }^{1}$, Stefania Arasi ${ }^{1}$, Anna Lucia \\ Piscitelli $^{1}$, Veronica Calandrelli ${ }^{1}$, Lamia Dahdah ${ }^{1}$, Vincenzo Fierro ${ }^{1}$, and Maurizio Mennini ${ }^{1}$ \\ ${ }^{1}$ Ospedale Pediatrico Bambino Gesu
}

January 10, 2022

\begin{abstract}
Background. The use of eliciting doses (EDs) for food allergens is necessary to inform individual dietary advice and food allergen risk-management. The Eliciting Dose 01 (ED01) for milk and egg, calculated from populations of allergic subjects undergoing diagnostic Oral Food Challenges (OFCs), are $0.2 \mathrm{mg}$ total protein. The respective Eliciting Dose 05 (ED05) are 2.4 $\mathrm{mg}$ for milk and $2.3 \mathrm{mg}$ for egg. As about $70 \%$ children allergic to such foods may tolerate them when baked, we sought to verify the EDs of that subpopulation of milk and egg-allergic children. Methods. We retrospectively assessed consecutive diagnostic OFC for fresh milk and egg between January 2018 and December 2020 in a population of baked food-tolerant children. Results. Among 288 children (median age 56 - IQR 36-92.5 months, 67.1\% male) included, 87 (30.2\%) returned positive OFC results, 38 with milk and 49 with egg. The most conservative ED01 were $0.3 \mathrm{mg}$ total protein (IQR 0.03-2.9) for milk and $14.4 \mathrm{mg}$ total protein (IQR 3.6-56.9) for egg. The respective ED05 were 4.2 (IQR 0.9-19.6) mg for milk and 87.7 (IQR 43-179) mg for egg. Such thresholds are respectively 1.5 (milk ED01), 1.75 (milk ED05), 72 (egg ED01), and 38.35 (egg ED05) times higher than the currently used thresholds. Conclusions The subpopulation of children allergic to milk and egg, but tolerant to baked proteins, displays higher reactivity thresholds than the general population of children allergic to milk and egg. Their risk stratification, in both individual and population terms, should consider this difference. In baked milk-tolerant children, milk causes reactions at lower doses than egg in our group of egg-tolerant children. This could be associated with the relative harmlessness of egg compared to milk in the determinism of fatal anaphylactic reactions in children
\end{abstract}

\section{Hosted file}

Threshold_6.1.22 freezed.docx available at https://authorea.com/users/371563/articles/552349reactivity-thresholds-in-children-allergic-to-cow-s-milk-and-egg-but-tolerant-of-bakedmilk-and-baked-egg

\section{Hosted file}

Table IV.docx available at https://authorea.com/users/371563/articles/552349-reactivitythresholds-in-children-allergic-to-cow-s-milk-and-egg-but-tolerant-of-baked-milk-andbaked-egg

\section{Hosted file}

Table I.docx available at https://authorea.com/users/371563/articles/552349-reactivitythresholds-in-children-allergic-to-cow-s-milk-and-egg-but-tolerant-of-baked-milk-andbaked-egg

\section{Hosted file}


Table II.docx available at https://authorea.com/users/371563/articles/552349-reactivitythresholds-in-children-allergic-to-cow-s-milk-and-egg-but-tolerant-of-baked-milk-andbaked-egg

\section{Hosted file}

Table III.docx available at https://authorea.com/users/371563/articles/552349-reactivitythresholds-in-children-allergic-to-cow-s-milk-and-egg-but-tolerant-of-baked-milk-andbaked-egg 